BARBARA GODARD is Associate Professor of English and Women's Studies at York University. Her translations include Nicole Brossard's These Our Mothers (1983) and Louhers (1986). She has also edited Gynocritics/Gynocritiques: Feminist Approaches to the Writing of Canadian and Quebec Women Writers (1987). Barbara Godard is a founding co-editor of Tessera.

\title{
Becoming My Hero, Becoming Myself: Notes Towards a Feminist Theory of Reading
}

BARBARA GODARD

This is a vast commonplace of literature: the Woman copies the Book. In other words, every body is a citation: of the "alreadywritten." The origin of desire is the statue, the painting, the book...

Roland Barthes, $S / Z$

What the reader has in common with the writer, though much more feebly (is) the desire to create.

Virginia Woolf, "Phases of Fiction"

Quotation is the most evident trace of reading: in becoming itself, my text will weave such threads into a new web, refocusing them in another context, giving them new meaning, which is to say rewriting them, in the continual teasing of memory and desire that is the texere. For reading is not just a deciphering of codes, it is a gesture of self-inscription.

"Re-vision" is how Adrienne Rich describes women's reading, that "act of looking back, of seeing with fresh eyes, of entering an old text from a new critical direction." Feminist readers have been eager to take up this challenge, looking back on literary history with female eyes which leads to a reconsideration of the literary institution, of both the canon and the process of reception and canonization. It also involves reexamination of the act of enunciation, that is of the production, reproduction and reception of the message.

Coming to voice in the current post-modernist era when critical focus has shifted away from text grammars, feminist theory has explored difference, problematizing language and the text by shifting attention to 
the ways in which meaning is produced. No longer is an author or speaker perceived to be a transcendent self or bearer of meaning (an authority), nor the text conceived as a self-contained object, the product of an expressive self to be consumed by an empathetic reader who reduplicates pre-constituted meanings. The text is neither discrete nor self-contained, but is constructed in the discourses that articulate it, in an interactive context of reader and text. Every text is a pre-text. The author, as reader, is rewriting precursor texts: the reader, as author, rewrites the author's text, investing it with meaning in the context of her own life and experience.

Feminist criticism has made us aware of the ways in which texts are "read" differently at different periods, according to the social conditions in effect and to the sexual identity of the reader. Readers actively and continuously participate in the creation of meanings in texts by bringing their own life and literary experiences to bear upon texts. "Life-to-text" interactions find readers using their knowledge of the world and their experience of being a woman in order to make sense of texts, while "text-to-life" interactions involve readers using textual knowledge to make sense of their lives, themselves socially constructed texts. For readers are members of different interpretive communities with varying histories and divergent horizons of expectation to bring to the text. Consequently, the meaning of the text is constructed within different discursive formations.

\section{WHAT ARE THE READERS?}

The gendered reader who may receive and construct a text is historically formed, shaped in and through language. Attention is focused on the processes by which reading subjects are caught up in, formed by and construct meanings. Representation of these meanings supports the fabrication of reality which can be known only through the forms that articulate it. In fact, reality is a fiction produced (coded) by its cultural representations. Currently, patriarchal relations set the terms for the forms of subjectivity available in reader-text relations, for woman does not represent, she is represented. Ideology's work is to fix meanings as timeless and im-

\section{WHO IS THE READER?}

A case history.

1948 - I read my first big novel, Swallows and Amazons. I dream of sailing over the waves in my own boat.

P.S. One of the joys of motherhood is rereading the novels I adored as a child. What good taste I had as a reader! My son agrees with me that Titty and Nancy, the more imaginative, adventurous and selfreliant characters, are the most interesting ones, even though they are girls... Amazons!

1955 - Whenever I have a cold, I go to bed with Jane Austen's novels. From Mrs. Bennett I learn that every young man in possession of a fortune is in search of a wife. With Elizabeth, I learn the heroine's plot, 
mutable above the field of material conditions in which they are constructed. But by posing the problem of sexual difference and representation as the fixing of difference, the relation of woman to that difference, then to come back to the indifference of the existing order, is to uncover the grounding and masking of male domination at the expense of women.

Feminist criticism explores the gendered reader's construction of textual order, an order which has hitherto been predominantly patriarchal. But within this feminist interpretive community, we discover a number of different reading practices that engage in varying subject/ object positions within the communicative act. What follows is a rough typology.

Seduced by the text, the female reader attempts to create herself as a male in order to become her hero. Mentally she catalogues the female characters in the books she reads as insipid or bitch goddesses, alienating herself from their life style, denying she is female. Intellectually a male, sexually a female, she is in fact a monstrous non-entity. In the process of activating black marks on the white page, this female reader has concluded that universal is not female: the word cannot be feminine. She has been forced to be complicit in her own "immasculation":! she has run the danger of collaborating in her own death.

However, the female reader faced with this power play to fuse her to the hero may become a "resisting" reader, a critical reader, a feminist reader. Alerted to the ways in which the marriage plot, the importance of men's money in making me an exceptional woman. Like Elizabeth, I am at home in father's library, so superior to other women. To remain a heroine, I must be chosen by the right man, the hero. From Emma, a voracious reader like myself, I learn the dangers of getting married to the wrong plot, of spinning the webs of fiction to marry my orphaned friend to the hero when I should marry him so as to choose to be myself. Dark secret, my compulsive reading makes me suspicious of all that talk at school about my growing up to be an ambassador - empty words. The plot to which my life is being shaped is that of lady of the manor.

What will I do then? My life will have no plot. Nobody writes about the lady in the manor. Unless she's Emma Bovary, confined to the role of insatiable reader, driven to death by the lack of outlet for her creative imagination.

1958 - I'm madly in love. Sitting at the back of the class, I write passionate letters to my love - in boarding school. I voice my desire in poems. In the library I find $D$. $H$. Lawrence's Women in Love which I read in class. I laugh so hard the teacher confiscates the book to quiet things down.

Laughing? How else can I respond to Gudrun's confusion and groping as she listens to her lover explain what she feels, when my desire is crystal clear and sharp. But the poems stop.

P.S. In 1971 I read Kate Millet's Sexual Politics and understand my 
woman is eternally the object, the absence, the minus in patriarchal discourse, the feminist reader confronts the issue of control. Who owns the meaning of the black marks on the page, the writer or the reader? Whose interests are served by them? She begins to explore the dual axes of what is in the text and what she brings to the text. Women's liberation movement becomes "readers' liberation movement.", 2

The feminist reader becomes aware of the double perspective possible in reading, from the object position (reading for the silences) or from the subject position. No longer is she positioned by the text to identify with the subject position. Aware of the power nexus, she is freed from being unknowingly bound by the text. She can begin to acknowledge the reality of her experience through her strong misreading of male texts. Resisting reading is the first step in the creation of her own life.

But what about women's texts? How does the feminist reader respond to them? Instead of battling her ways out of a structure constructed to enclose her, a feminist reader may enter into dialogue with a female writer. The reader may give up the struggle to control the text, abandon the power game entirely, in an effort to connect with the woman behind the text. Such empathetic reading is constructed on an intersubjective encounter with the heart and mind of another woman. To read Susanna Moodie, as Margaret Atwood shows us, is to bring her to life again, in us. We seek to understand the writer's life derision for a classic. I approve my instinctive rejection of misogyny.

1959 - Was I right to laugh? Where will laughter bring me? I am devouring Edith Wharton's novels, reading the House of Mirth - with great fear. If I continue as I am, will I become Lily Bart, a woman of slender means, living by my wits in high society? All is well while Lily is young and has expectations. Time passes and she cannot choose, nor is she chosen. Lily wants a marriage of true minds: men are afraid of her wit. She cannot remain a heroine and work to support herself. She puts an end to her life. Help! This is not the script for the heroine I was shaping myself to be!

P.S. At the time, I didn't understand all this. I just read and read. Only twenty years later, when I had begun to reflect on my life as a reader and offered to lecture on some of the women writers I had found in the library, but never studied formally, did I begin to see how becoming a hero, or more precisely a shero, is a mode of self-discovery. In writing the words to share with other readers, I give voice to the conflict between my life as a reader and real life. I become more and more intrigued by the way in which the self and self-consciousness are mutually involved and shaped in/by literary form and language.

1962 - An English major at university, 1 read all the time, Chaucer, Milton, Spenser, Shakespeare - the canon. I go to scholars' night in my black skirt, white shirt, and my father's black tie, an honorary male. 
so that we may enter into it. We try to shape our lives as heroes: we may become ourselves. Our drive to connect flows in the blood. To the text we bring our biological lives as women. Between the lines of the female text, unverbalized, we read the hidden text of our bodily experience. Blood line, life line, poetic line. Acknowledging this rich silence informing the female text is to validate our experience as women. No longer monsters with male minds, we recognize the creative powers of the female imagination. The word takes on flesh of woman and gives birth to us. Through the complicity of reading, we have a single reader, a single text. At the heart of the communicative process, the subject/object relationship is transformed into the singular experience of a female subject shaping her life as writer.

MERGING may become a complication here, as it is for the reader seduced to align herself with masculine authorial power. She loses herself in the other. An alternative may be found in the dialogue, in a differential process of reading when subject and object beome the onewithin-the-other, double, polyphonic, not singular. Here the double context of reading and writing comes into play. Plurality of the subject, threatened by merging in a complicit reading, is mediated by an awareness of different contexts for reading and writing. Grounded in the rich context of her own experience, the reader enters into the context of the writer as a visitor. She must not impose herself on the other. Instead, she seeks to establish
I write papers on allegory, on the Nature meditation - Wordsworth, Coleridge, Shelley. But sometimes I still read as a woman. Henry James' Portrait of a Lady irritates me. How could Isabel be so silly as to let herself be chosen by the wrong man, by the one who treats her as an object, not a person? I tell the Professor that James doesn't undestand female psychology, so much for his famous realism. Not convinced, he replies that my anger is proof she is a real person. I know I've been had, but I have no words to answer.

1963 - In the summer I read $M \dot{e}$ moires d'une jeune fille rangée and Le deuxième sexe with excitement. I've discovered the story of my life, my conflict with bourgeois society, and read my inchoate emotions shaped into a theory about women's marginalization in society, which is enforced by the plots of fiction! Now I have a new hero and a different script for my life. To my surprised friends, I announce that I'll never marry but like Simone de Beauvoir keep my independence and live by my pen. This new insight gives me courage: I challenge the professor about the lack of women writers on the course. $\mathrm{He}$ introduces me to Sheila Watson's The Double Hook. Soon I read Virginia Woolf for the first time. I am overwhelmed. There has been nothing like this before. I empty the library of everything she has written. The writing begins by itself in response to my desire to enter the world she created. I analyse her sentences, the shape of her essays. Her words become my words. Trace of reading becomes writing. $\mathrm{Pa}$ - 
a play of affinities and differences by reminding herself of the context of her own reading and of the writer's very different context of creating. The woman writer explores her life as a reader in order to come to writing. In this way, she discovers and foregrounds the work of reading, its powers to create and construct meaning.

In The Diviners by Margaret Laurence, Morag, the modern writer living by the river, calls up the ghost of Catherine Parr Traill, pioneer writer who lived in a cottage by the same river. She tries to merge her life-story with that of her hero, Saint Catherine Traill, who combines the rich practical skills as a housewife with her role as pioneering writer charting new terrain. Under the control of her model, the writer is only reader, not able to recognize and exert her creative powers, silenced by writer's block. When at last she acknowledges the different context in which her model lived and wrote, the writing about housework and nature coming out of the circumstances of her pioneer existence, the reader becomes aware of writing as productivity, as transformation, grounded in this case, in the material practices of women's domestic labour. She sees it as the shaping of meaning in the context of a specific life experience.

The new writer becomes free to write her own life into another shape based on her different experience, where she will not be a superwoman and saint able to do everything, but merely a writer. Simultaneously, she is able to let her stiche. Respectful parody. MERGING. Un(self)conscious.

1969 - Unlike the plots of art, those of life have many peripateiae. The writing no longer seeks to merge with its object. I am detached, analytical. Too much so. Intellectually a male, I write about the Organization Man and the American War Novel, a thesis to prove my "seriousness" and get me a job. Men's money. The heroine's plot! In my father's library. Sexually I am a conventional female, I have married.

1971 - I read Sexual Politics and remember reading Lawrence with derision. But I am busy on a study of Man and the Land in the novel of the two Canadas. It gets me a job.

1978 - Into mid-life crisis, I am trying to make sense of my life, to see what plot has shaped it. My first rite of passage found me a nationalist. Now I realize I have always been a feminist too. What took me so long to see this? In thinking about my life as a reader I come to recognize I have always read women writers differently from men, seeking to learn about myself from one group, about the world around me from the other, I have constructed different meanings from these experiences, delighting in the play of affinities and differences. I become aware of the complexity of my motives as a reader, of the many different reasons for which I read, and of the many different interpretive communities to which I belong. Many people are talking about what it means to read as a Canadian, as a socialist, but 
own daughter (or character) go free to write her songs out of a different life line. This is what it means to mother a text: to let the daughter tell her own story. To enter into a loving and reciprocal relationship with the other. The woman writer rewrites the Great Tradition to replace fathering by mothering the text. Laurence rewrites Shakespeare's Prospero/Miranda story to show what the relationship between parent/child, author/creature, writer/reader is like when the magician abdicates his power over the word and the knowledge it permits, ceases to be an authority and lets everyone tell or write their own story.

What results is a circulation of narratives that acknowledge different contexts of writing and reading. Such narratives of maternal difference are orchestrations of many different writing contexts -communal texts which subvert authority. They provide a model of reading and rewriting as the exchange of life stories. what about reading as a woman? For so long I have been doing this without thinking about it. Now I begin to reflect on this submerged life.

I hear about a conference on women writers, write a paper on women and language in The Double Hook and go along. Here many other women are struggling to find the words to write about their experience reading women writing. They help me in my search for the words to articulate this different reading experience. Strengthened, I go back to the university to fight for a course on women's writing. I talk and talk about my story as a reader, for this is what I share with the readers who are in my classes. I struggle to open shared spaces for writers and readers to meet, in coferences, books and Tessera. I begin to translate women writers -.- Antonine Maillet, Louky Bersianik, Nicole Brossard and others. Reading and decoding their texts, I recode and rewrite them. The words pour forth in other translations, in active readings become writing in a new context. Transformations. The words pour forth.

1984 - I write "Reading Women Writing: The case of Contemporary Canada."

1985 - "The author, as reader, is rewriting precursor texts: the reader, as author, rewrites the author's text, investing it with meaning in the context of her own life and experience."

I quote from "Reading Women Writing" and I unfold the plot of my life as a reader as I write "Becoming My Hero, Becoming Myself." 


\section{NOTES}

1. Judith Fetterley: The Resisting Reader: A Feminist Approach to American Fiction (Bloomington: Indiana University Press, 1978), xxii.

2. Terry Eagleton, "The Revolt of the Reader," New Literary History, 13, No. 3 (1982), 449. 